\title{
Removal of fluoride from semiconductor wastewater by electrocoagulation-flotation
}

\author{
C.Y. Hu ${ }^{\text {a }}$, S.L. Lo ${ }^{a}$, W.H. Kuan ${ }^{\text {b,* }}$, Y.D. Lee ${ }^{\mathrm{a}}$ \\ ${ }^{a}$ Research Center for Environmental Pollution Prevention and Control Technology, Graduate Institute of Environmental Engineering, \\ National Taiwan University, Taipei 106, Taiwan \\ ${ }^{\mathrm{b}}$ Department of Environmental and Safety Engineering, Ming-Chi University of Technology, 84 Gunjuan Road, Taishan, \\ Taipei Hsien 243, Taiwan
}

Received 24 February 2004; received in revised form 5 November 2004; accepted 28 November 2004

\begin{abstract}
This work employs an anodic surfactant, sodium dodecyl sulfate (SDS), to improve the flotation performance of the electrocoagulation-flotation (ECF) process to treated fluoride containing semiconductor wastewater following calcium precipitation. The dissolved fluoride ions and $\mathrm{CaF}_{2}$ particles in the wastewater after calcium precipitation were effectively removed in the ECF process simultaneously. The dosage of SDS required for ECF was much less than those for dispersed air flotation (DiAF) or dissolved air flotation (DAF) processes because the $\mathrm{CaF}_{2}$ particles can be collected by hydro-fluoro-aluminum flocs in ECF. Thus, SDS only served as a frother to make the bubbles tiny and stable in the ECF defluoridation process. The interference of co-existing anions can be overcome by increasing the dosage of calcium ions and SDS. The optimum initial acidity for ECF is close to the initial fluoride concentration after calcium precipitation; the amount of SS removed dropped rapidly if the initial acidity exceeded the optimal value because the surface charge of the hydro-fluoro-aluminum particles increased. The initial acidity of the wastewater after calcium precipitation can be modified by changing the $\left[\mathrm{Ca}(\mathrm{OH})_{2}\right] /\left[\mathrm{Ca}^{2+}\right]_{\mathrm{T}}$ ratio and the appropriate ratio is approximately given by the acid dissociation constant of hydrofluoric acid and the initial $\mathrm{pH}$ of the wastewater before calcium precipitation. (C) 2005 Elsevier Ltd. All rights reserved.
\end{abstract}

Keywords: Sodium dodecyl sulfate (SDS); Fluoride; Electrocoagulation-flotation (ECF); Calcium precipitation

\section{Introduction}

An appropriate concentration of fluoride in drinking water is required to prevent dental cavities, but longterm ingestion of water that contains more than a suitable level of fluoride causes bone disease and mottling of the teeth (Brown et al., 1977; Lynch, 1987; Nell and Livanos, 1988). The suitable level of fluoride in

\footnotetext{
*Corresponding author. Tel.: +886229089899x4653; fax: +886229041914 .

E-mail address: whkuan@ccsun.mit.edu.tw (W.H. Kuan).
}

drinking water specified by the World Health Organization (WHO) is $1.5 \mathrm{mg} \mathrm{L}^{-1}$ (Mansson and Withford, 1990). The discharge standard of fluoride in industrial wastewater is $15 \mathrm{mg} \mathrm{L}^{-1}$ in Taiwan.

Treatment of fluoride-containing wastewater efficiently has been important for environmental engineers in Taiwan, following the fast development of the semiconductor industry. Around $350-700 \mathrm{~m}^{3} \mathrm{day}^{-1}$ of fluoride-containing wastewater, with fluoride concentrations from 500 to $2000 \mathrm{mg} \mathrm{L}^{-1}$ is generated by the rinsing and cleaning operations in a typical 8-in semiconductor fabrication facility (Huang and Liu, 


\begin{tabular}{|llll|}
\hline \multicolumn{2}{l}{ Nomenclature } & $R$ & ideal gas constant $\left(R=8.14 \mathrm{~J}^{0} \mathrm{~K}^{-1} \mathrm{~mol}^{-1}\right)$ \\
& $t$ & reaction time $(\mathrm{s})$ \\
{$\left[\mathrm{F}^{-}\right]_{0}$} & initial fluoride concentration $\left(\mathrm{kg} \mathrm{m}^{-3}\right)$ & $T$ & temperature $\left({ }^{\circ} \mathrm{K}\right)$ \\
{$\left[\mathrm{F}^{-}\right]_{\text {res }}$} & residual fluoride concentration $\left(\mathrm{kg} \mathrm{m}^{-3}\right)$ & $V$ & volume of the solution $\left(\mathrm{m}^{3}\right)$ \\
$F$ & faraday constant, $F=96487\left(\mathrm{C} \mathrm{mol}^{-1}\right)$ & $V_{\mathrm{H}_{2}}$ & volume of the hydrogen gas $\left(\mathrm{m}^{3}\right)$ \\
$I$ & current $(\mathrm{A})$ & $Z$ & valence \\
$K_{\mathrm{HF}}$ & dissociation constant of hydrofluoric acid & $\varepsilon_{\mathrm{F}}$ & treatment efficiency of fluoride $(\%)$ \\
& $\left.(\text { mol m})^{-3}\right)$ & $\varepsilon_{\mathrm{SS}}$ & treatment efficiency of suspended solids $(\%)$ \\
$n$ & cells number $(n=6$ in all systems $)$ & $\gamma_{\text {theo }}$ & estimated appropriate $\left[\mathrm{Ca}(\mathrm{OH})_{2}\right] /\left[\mathrm{Ca}^{2+}\right]_{\mathrm{T}}$ \\
$P$ & atmosphere pressure $\left(\mathrm{N} \mathrm{m}^{-2}\right)$ & & ratio $(\%)$ \\
$Q_{\mathrm{e}}$ & charge loading $\left(\mathrm{Cm}^{-3}\right)$ &
\end{tabular}

1999; Chuang et al., 2002). Presently, the cheapest way to remove fluoride from semiconductor wastewater is to produce calcium fluoride $\left(\mathrm{CaF}_{2}\right)$ by adding lime or another calcium salt, such as $\mathrm{CaCl}_{2}$.

$\mathrm{Ca}_{(\mathrm{aq})}^{2+}+2 \mathrm{~F}_{(\mathrm{aq})}^{-} \rightarrow \mathrm{CaF}_{2(\mathrm{~s})}$.

However, this process causes the problem of hardness of the effluent water. The theoretical concentration of fluoride is $8-12 \mathrm{mg} \mathrm{L}^{-1}$ when stoichiometric amount of calcium salt is added (Huang and Liu, 1999; Chuang et al., 2002; Buffle et al., 1985; Parthasarathy et al., 1986). Unfortunately, this result is not obtained in practice because of high ionic strength, slow nucleation and low pH (Buffle et al., 1985; Parthasarathy et al., 1986). Hence, the amount of calcium salt added often exceeds the stoichiometric amount and the hardness of the effluent water may exceed $1000 \mathrm{mg} \mathrm{L}^{-1}$ as $\mathrm{CaCO}_{3}$.

Another problem associated with calcium precipitation is that the particles of $\mathrm{CaF}_{2}$ are too fine to be sedimented without coagulation. Aluminum salts are typically used as a coagulant following calcium precipitation. The aluminum salts are also useful absorbents or coagulants for removing fluoride (Huang and Liu, 1999; Chuang et al., 2002; Buffle et al., 1985; Parthasarathy et al., 1986). Co-precipitation (Eq. (2)) or adsorption reactions (Eq. (3)) may occur when an appropriate quantity of aluminum salt is added to a fluoride-containing solution.

$$
\begin{aligned}
& n \mathrm{Al}_{(\mathrm{aq})}^{3+}+3 n-m \mathrm{OH}_{(\mathrm{aq})}^{-}+m \mathrm{~F}_{(\mathrm{aq})}^{-} \\
& \quad \rightarrow \mathrm{Al}_{n} \mathrm{~F}_{m}(\mathrm{OH})_{3 n-m(\mathrm{~s})} \\
& \mathrm{Al}_{n}(\mathrm{OH})_{3 n(\mathrm{~s})}+m \mathrm{~F}_{(\mathrm{aq})}^{-} \\
& \quad \rightarrow \mathrm{Al}_{n} \mathrm{~F}_{m}(\mathrm{OH})_{3 n-m(\mathrm{~s})}+m \mathrm{OH}_{(\mathrm{aq})}^{-} .
\end{aligned}
$$

If the quantity of fluoride removed by co-precipitation or adsorption with $\mathrm{Al}(\mathrm{III})$ salts after calcium precipitation can be determined, then the amount of calcium salt added can be reduced.

An electrochemical method (electrocoagulation, EC) has been employed to perform defluoridation (Lui et al., 1983; Mameri et al., 1998; Mollah et al., 2001; Hu et al.,
2003; Shen et al., 2003). Al(III) ions and hydrogen gas are produced stoichiometrically and simultaneously when electric current passes through the aluminum electrodes.

$\mathrm{Al}_{(\mathrm{s})} \rightarrow \mathrm{Al}_{(\mathrm{aq})}^{3+}+3 \mathrm{e}^{-}$,

$2 \mathrm{H}_{2} \mathrm{O}_{(\mathrm{l})}+2 \mathrm{e}^{-} \rightarrow 2 \mathrm{OH}_{(\mathrm{aq})}^{-}+\mathrm{H}_{2(\mathrm{~g})}$.

The semiconductor wastewater after calcium precipitation contains both suspended solid (SS) and soluble fluoride ions. Both of the pollutants can be removed simultaneously in the EC process. The $\mathrm{CaF}_{2}$ particles can be removed by coagulation of $\mathrm{Al}(\mathrm{III})$ ions, flotation of hydrogen gas or a combination thereof (Lui et al., 1983; Mollah et al., 2001), and the fluoride ions can be removed by coagulation of $\mathrm{Al}$ (III) ions.

Some researchers call the EC process the electrocoagulation-flotation (ECF) process because they emphasize the flotation performance of EC (Jiang et al., 2002; Murugananthan et al., 2004). The duration of the flotation is much shorter than that of sedimentation. Less land, therefore, is needed for the treatment plant. The particles of $\mathrm{CaF}_{2}$, however, cannot be completely removed by flotation in a conventional ECF process. Most of the hydrogen bubbles generated from the cathodes combine together because hydrogen gas is hydrophobic. The flotation efficiency decreases with the increase of bubble size because the total surface area and retention time of large bubbles are less than those of small bubbles.

Surfactants are employed as a frother to reduce the surface tension of solutions and thus make gas bubbles finer and more stable during dispersed air flotation (DiAF) and dissolved air flotation (DAF) (Huang and Liu, 1999; Chuang et al., 2002). Furthermore, they are also employed as a collector to increase the collective efficiency of the bubbles. Huang and Liu (1999) successfully applied an anodic surfactant, sodium dodecyl sulfate (SDS), to improve the treatment efficiency of the $\mathrm{CaF}_{2}$ particles in DiAF. They noted that adsorption of SDS onto the $\mathrm{CaF}_{2}$ surface through 
electrostatic interaction enhances the hydrophobicity of the $\mathrm{CaF}_{2}$ surface.

This study attempted to employ SDS to enhance the flotation capacity of ECF to remove the dissolved fluoride ions and $\mathrm{CaF}_{2}$ particles simultaneously in the semiconductor wastewater following calcium precipitation. The semiconductor wastewater is first treated by the conventional precipitation process with calcium salts and then polished by the proposed ECF process. The effects of four parameters - the concentration of SDS, the charge loading, the initial acidity of the solution and the species and concentrations of co-existing anions on the efficiency of treatment of the fluoride ions and $\mathrm{CaF}_{2}$ particles were investigated with synthetic solution. Finally, wastewater with a high fluoride concentration from a semiconductor manufacturer was used to elucidate the performance of treatment using ECF.

\section{Materials and methods}

Experiments were conducted in a bipolar batch reactor with seven aluminum electrodes connected in parallel, as in the authors' previous work ( $\mathrm{Hu}$ et al., 2003). A constant current was maintained using a potentiostat in intensiostat mode. The volume $(V)$ of the solution in each batch was 11 . Magnetic stirring at $400 \mathrm{rpm}$ maintained a homogeneous solution in the batch reactor.

Synthetic solutions were prepared by mixing stoichiometric amounts of sodium fluoride $(500 \mathrm{mg}$ as F) and calcium chloride $\left(2.13 \mathrm{~g}\right.$ as $\left.\mathrm{CaCl}_{2} \cdot 2 \mathrm{H}_{2} \mathrm{O}\right)$ with D.I. water (11) to simulate the semiconductor wastewater after calcium precipitation. The initial fluoride concentration and SS in the synthetic solution were 27.8 and $832 \mathrm{mg} \mathrm{L}^{-1}$, respectively. Various amounts of SDS stock solution were added to the synthetic solution to investigate the influence of SDS concentration on the performance of ECF process. The charge loading $\left(Q_{\mathrm{e}}\right)$ is defined as the charge applied per liter of solution

$Q_{\mathrm{e}}=\frac{n I t}{V}$.

The effect of $Q_{\mathrm{e}}$ on the performance of ECF process was examined by changing the electric current. After the suitable SDS and $Q_{\mathrm{e}}$ were specified, various quantities of $\mathrm{Na}_{2} \mathrm{SO}_{4}$ (Merck, 99\%), $\mathrm{NaHCO}_{3}$ (Merck, 99\%) or
$\mathrm{NaH}_{2} \mathrm{PO}_{4}$ (Acros, 99\%) were added to the solutions to investigate the interference of co-existing anions. The effect of acidity on the ECF process was tested by adding a different amount of $1.0 \mathrm{M}$ stock solution of $\mathrm{HCl}$ to the synthetic solution.

Wastewater was taken from a semiconductor manufacturer in Taiwan. The quality parameters of wastewater are shown in Table 1 . The concentration of suspended solid was very low $\left(<2 \mathrm{mg} \mathrm{L}^{-1}\right)$, so $\mathrm{CaF}_{2}$ was presumed to be the only source of suspended solid after precipitation. The initial $\mathrm{pH}$ of the wastewater was 2.52 . Measured amounts of $\mathrm{CaCl}_{2}$ and $\mathrm{Ca}(\mathrm{OH})_{2}$ salts were added to the wastewater to precipitate the fluoride ions and adjust the $\mathrm{pH}$. The total fluoride $\left([\mathrm{F}]_{\mathrm{T}}\right)$ and total calcium dosage $\left(\left[\mathrm{Ca}^{2+}\right]_{\mathrm{T}}\right)$ were stoichiometric $\left(2\left[\mathrm{Ca}^{2+}\right]_{\mathrm{T}}=[\mathrm{F}]_{\mathrm{T}}\right)$.

A $100 \mathrm{ml}$ volume of treated solution was sampled 5 min after the reaction was complete. SS was measured by a modified method described by Huang and Liu (1999). The membrane filter used in this method is $0.2 \mu \mathrm{m}$ to prevent the fine $\mathrm{CaF}_{2}$ particles from flowing through the filter. The concentration of fluoride and the $\mathrm{pH}$ were measured using a specific fluoride electrode (Orion Research Inc., ion plus fluoride 9609BN, USA) and $\mathrm{pH}$ electrode, respectively. The TISAB II buffer solution containing CDTA (trans-1,2-Diaminocyclohexane- $N, N, N^{\prime}, N^{\prime}$-tetra-acetic acid, Orion Research Inc.) was added to the samples to prevent interference from other ions $\left(\mathrm{Al}^{3+}, \mathrm{Fe}^{3+}\right.$, etc.) during the measurement of the fluoride concentration (Hao and Huang, 1986) . Zeta potential of the hydro-fluoroaluminum precipitate was analyzed by a zeta meter (Photo ELS-600).

\section{Results and discussion}

\subsection{Effect of SDS concentration}

Fig. 1 presents the effect of SDS concentration on the treatment efficiency of SS and fluoride. The residual fluoride concentration ranged from 5.0 to $6.0 \mathrm{mg} \mathrm{L}^{-1}$ and was unaffected by SDS concentration. The residual fluoride concentration herein is less than the one reported in the DiAF $\left(12 \mathrm{mg} \mathrm{L}^{-1}\right)$ (Huang and Liu, 1999) or DAF (10.3-10.9 $\left.\mathrm{mg} \mathrm{L}^{-1}\right)$ process (Chuang

Table 1

Quality parameters of wastewater

\begin{tabular}{llllllll}
\hline Parameter & $\mathrm{F}^{-}$ & $\mathrm{Cl}^{-}$ & $\mathrm{NO}_{3}^{-}$ & $\mathrm{Na}^{+}$ & $\mathrm{K}+$ & $\mathrm{Mg}^{2+}$ & $\mathrm{Ca}^{2+}$ \\
\hline Concentration $\left(\mathrm{mg} \mathrm{L}^{-1}\right)$ & 806 & 13 & 31 & 328 & 5.03 & 3.93 & 13.9 \\
\hline
\end{tabular}

Anions were measured by an ion chromatograph (Dionex, DX-100). Cations were measured by an inductively coupled plasma atomic emission spectrophotometer (ICP-AEC, Model JY24, Jobinyvon). 


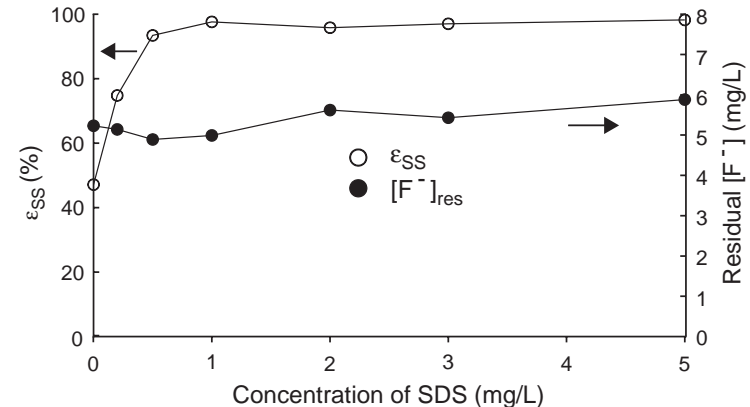

Fig. 1. The variation of the treatment efficiency of SS $\left(\varepsilon_{\mathrm{ss}}\right)$ and residual fluoride concentration with the concentration of SDS (initial $\mathrm{SS}=832 \mathrm{mg} \mathrm{L}^{-1},[\mathrm{~F}-]_{0}=27.4 \mathrm{mg} \mathrm{L}^{-1}$, $\left.Q_{\mathrm{e}}=720 \mathrm{C} \mathrm{L}^{-1}\right)$.

et al., 2002), when stoichiometric amounts of calcium salt were added, probably because of the adsorption or co-precipitation of fluoride with aluminum ions (Eqs. (1) and (2)).

The concentration of SDS considerably influenced the efficiency of SS removal $\left(\varepsilon_{\mathrm{SS}}\right)$. The $\varepsilon_{\mathrm{SS}}$ without SDS was $47.1 \%$. It rose drastically to $74.6 \%$ when $0.2 \mathrm{mg} \mathrm{L}^{-1}$ of SDS was added and reached $97.6 \%$ when $1.0 \mathrm{mg} \mathrm{L}^{-1}$ of SDS was added. Notably, the concentration of SDS required to remove SS herein was much less than that required for $\operatorname{DiAF}\left(50 \mathrm{mg} \mathrm{L}^{-1}\right)$ (Huang and Liu, 1999), because the $\mathrm{Al}^{3+}$ ions cause coagulation. In the ECF system, however, the $\mathrm{Al}^{3+}$ ions, which were released from the anodes, hydrolyzed to form aluminum hydroxide flocs. The flocs aggregated the $\mathrm{CaF}_{2}$ particles and the hydrogen gas bubbles. Hence, SDS is only a frother not a collector in the ECF system. Therefore, the SDS dosage does not need to be as high as in the DiAF process.

\subsection{Effect of charge loading}

Fig. 2 plots the effect of $Q_{\mathrm{e}}$ on the $\varepsilon_{\mathrm{SS}}$ and the residual concentration of fluoride ions. The removal of SS and fluoride both increased with $Q_{\mathrm{e}}$. According to Faraday's Law, the concentration of $\mathrm{Al}(\mathrm{III})$ ions released from anodes can be calculated by

$\left[\mathrm{Al}^{3+}\right]=\frac{Q_{\mathrm{e}}}{Z F}, \quad Z=3$ for $\mathrm{Al}(\mathrm{III})$.

Combining Faraday's Law and the ideal gas law, the volume of hydrogen gas generated $\left(V_{\mathrm{H}_{2}}\right)$ is given by

$V_{\mathrm{H}_{2}}=\frac{V R T Q_{\mathrm{e}}}{Z F P}, \quad Z=2$ for $\mathrm{H}_{2}$.

The $\mathrm{Al}^{3+}$ ions form aluminum hydroxide flocs to remove fluoride ions and hydrogen gas bubbles remove SS in ECF, so naturally, the residual fluoride concentration and SS both decline as $Q_{\mathrm{e}}$ increases.

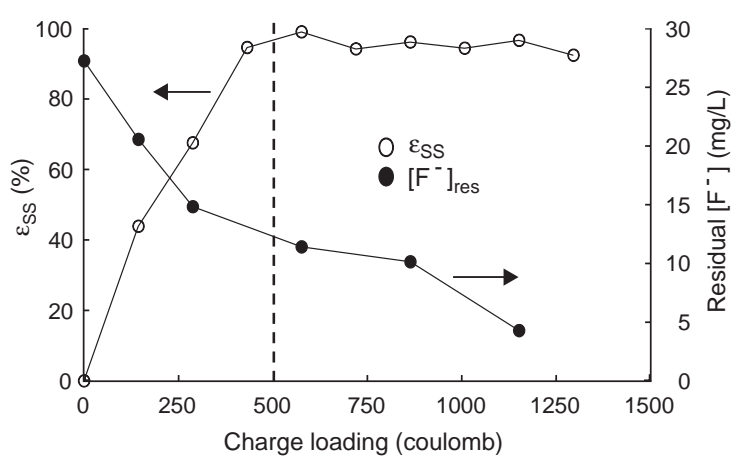

Fig. 2. The variation of the treatment efficiency of SS $\left(\varepsilon_{\mathrm{sS}}\right)$ and residual fluoride concentration with charge loading (initial $\mathrm{SS}=832 \mathrm{mg} \mathrm{L}^{-1},[\mathrm{SDS}]=5 \mathrm{mg} \mathrm{L}^{-1}$ ).

Notably, when $Q_{\mathrm{e}}$ exceeded $500 \mathrm{CL}^{-1}$, the $\varepsilon_{\mathrm{SS}}$ remained at $95 \%$, but the residual fluoride concentration was still reducing as $Q_{\mathrm{e}}$ was increasing. This phenomenon indicates that only the relationship between $Q_{\mathrm{e}}$ and $\varepsilon_{\mathrm{F}}$ needs to be considered if $Q_{\mathrm{e}}$ exceeds $500 \mathrm{C} \mathrm{L}^{-1}$.

\subsection{Effect of initial acidity}

The $\mathrm{pH}$ of a solution is one of the most important parameters that govern the removal of fluoride in both the electrocoagulation and flotation processes (Lui et al., 1983; Mameri et al., 1998; Mollah et al., 2001; Shen et al., 2003; Matis and Mavros, 1991; Lin and Liu, 1996). Controlling the $\mathrm{pH}$ of the solutions, however, is very difficult during the ECF process because the defluoridation reaction (Eqs. (1) and (2)) changes the $\mathrm{pH}$ and the applied current may interfere with the measurement of $\mathrm{pH}$. Moreover, controlling the initial $\mathrm{pH}$ in the ECF system is not very useful to vary the final $\mathrm{pH}$. The final $\mathrm{pH}$ and residual fluoride concentration did not change very much in the range of initial $\mathrm{pH}=4-8$ in the EC defluoridation process because of the buffer capacity of aluminum hydroxide (Mameri et al., 1998; Shen et al., 2003). Therefore, the initial acidity was varied to investigate the effect of so doing on the final $\mathrm{pH}$ and the treatment efficiency of SS and fluoride. Table 2 presents the variation of final $\mathrm{pH}$ with the initial acidity of the solution. The final $\mathrm{pH}$ fell from 8.6 to 6.3 as the initial acidity rose from near 0 to $2.5 \mathrm{mM}$ as $\mathrm{H}^{+}$. Although the final $\mathrm{pH}$ did not change very much, the treatment efficiency of SS did. Fig. 3 plots the variation of $\varepsilon_{\mathrm{SS}}$ and the residual fluoride concentration with the final $\mathrm{pH}$ of the solution. The $\varepsilon_{\mathrm{SS}}$ decreased significantly as the final $\mathrm{pH}$ of the solution dropped to 6.3. This phenomenon occurred probably because $\mathrm{CaF}_{2}$ electrostatically repels the hydro-fluoro-aluminum particles. Fig. 4 shows the zeta potential of the hydro-fluoro-aluminum particles against $\mathrm{pH}$. The surface charge of the 
Table 2

The variation of initial and final $\mathrm{pH}$ with the initial acidity of solution

\begin{tabular}{lcccccc}
\hline Initial acidity $\left(\mathrm{mM}\right.$ as $\left.\left[\mathrm{H}^{+}\right]\right)$ & $\approx 0$ & 0.5 & 1.0 & 1.5 & 2.0 & 2.5 \\
\hline Initial pH & 5.1 & 3.3 & 3.1 & 2.8 & 2.7 & 2.6 \\
Final pH & 8.6 & 8.3 & 7.5 & 7.2 & 6.9 & 6.3 \\
\hline
\end{tabular}

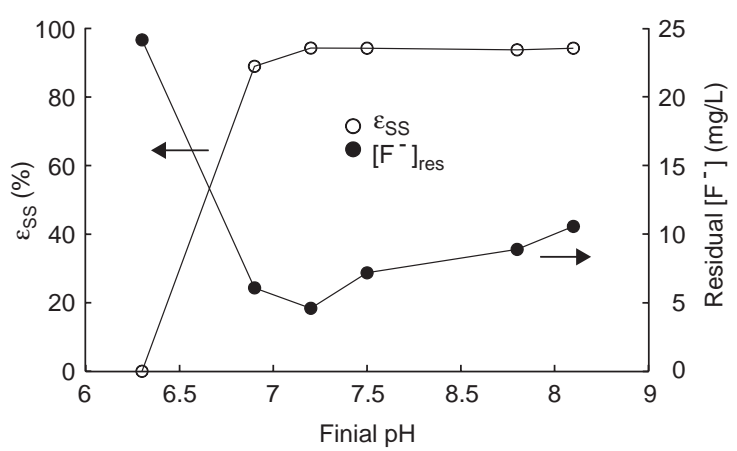

Fig. 3. The variation of the treatment efficiency of SS $\left(\varepsilon_{\mathrm{ss}}\right)$ and residual fluoride concentration with the final $\mathrm{pH}$ $\left(Q_{\mathrm{e}}=864 \mathrm{CL}^{-1},[\mathrm{SDS}]=5 \mathrm{mg} \mathrm{L}^{-1}\right)$.

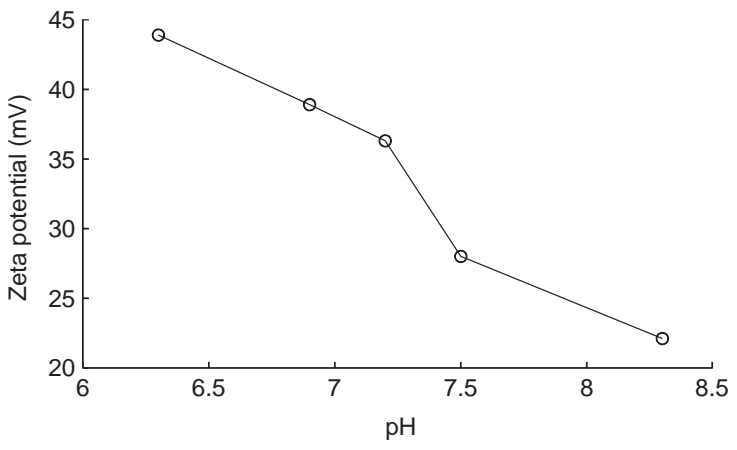

Fig. 4. The variation of zeta potential of the hydro-fluoro-aluminum with the final $\mathrm{pH}$.

hydro-fluoro-aluminum precipitate increased as $\mathrm{pH}$ declined. As stated above, the surface charge of $\mathrm{CaF}_{2}$ particles is strongly positive. Hence, the hydro-fluoro-aluminum precipitate could not aggregate the $\mathrm{CaF}_{2}$ particles to form stable flocs if they were also strongly positive.

The residual fluoride concentration also increased as the final $\mathrm{pH}$ dropped to 6.3 because the solubility of the hydro-fluoro-aluminum precipitate increased. The same result was also observed elsewhere (Shen et al., 2003). Notably, the treatment efficiency of fluoride was optimal when the initial acidity was very close to the initial fluoride concentration
$\left(\left[\mathrm{H}^{+}\right]_{0} \approx\left[\mathrm{F}^{-}\right]_{0}=27.8 \mathrm{mg} \mathrm{L}^{-1}=1.46 \mathrm{mM}\right)$ and the final $\mathrm{pH}$ was around seven. Combining Eqs. (3)-(5) yields

$$
\begin{aligned}
& n \mathrm{Al}_{(\mathrm{s})}+3 n \mathrm{H}_{2} \mathrm{O}_{(\mathrm{l})}+m \mathrm{~F}_{(\mathrm{aq})}^{-} \\
& \quad \rightarrow \mathrm{Al}_{n} \mathrm{~F}_{m}(\mathrm{OH})_{3 n-m(\mathrm{~s})}+m \mathrm{OH}_{(\mathrm{aq})}^{-}+1.5 n \mathrm{H}_{2(\mathrm{~g})} .
\end{aligned}
$$

Eq. (9) reveals that the hydroxide ions liberated from the defluoridation reaction can be completely neutralized if the initial acidity equals the initial concentration of the fluoride. The solution was therefore neutral and the treatment efficiency of fluoride was optimal when the initial acidity equaled the initial concentration of the fluoride.

\subsection{Effect of co-existing anions}

Some co-existing anions may be present in the fluoride-containing wastewater. Among these co-existing anions, $\mathrm{SO}_{4}^{2-}, \mathrm{HCO}_{3}^{-}$and $\mathrm{H}_{2} \mathrm{PO}_{4}^{-}$should be considered carefully because competition between fluoride and these anions for calcium may reduce $\varepsilon_{\mathrm{F}}$. Additionally, the competition between SDS and these anions for adsorption sites on $\mathrm{CaF}_{2}$ may also decrease the $\varepsilon_{S S}$ (Huang and Liu, 1999; Chuang et al., 2002).

Table 3 presents the effect of the concentration of $\mathrm{SO}_{4}^{2-}, \mathrm{HCO}_{3}^{-}$and $\mathrm{H}_{2} \mathrm{PO}_{4}^{-}$on $\varepsilon_{\mathrm{SS}}$ and residual concentration of fluoride. Clearly, all three co-existing anions reduced $\varepsilon_{\mathrm{SS}}$ and $\varepsilon_{\mathrm{F}}$. The residual concentration of fluoride increased from 56 to $82 \mathrm{mg} \mathrm{L}^{-1}$ and the residual SS rose from 20.4 to $129 \mathrm{mg} \mathrm{L}^{-1}$ as the sulfate concentration increased from 0.001 to $0.01 \mathrm{M}$. A similar effect was observed as the other two anions were added.

Increasing the concentrations of SDS and calcium increased the treatment efficiencies of SS and fluoride. Fig. 5 show the variation of $\varepsilon_{S S}$ and residual fluoride concentration with the concentration of SDS under interference among various co-existing anions after the calcium concentration is increased to the stoichiometric value (ex. $\left.\left[\mathrm{Ca}^{2+}\right]=0.5\left[\mathrm{~F}^{-}\right]+\left[\mathrm{SO}_{4}^{2-}\right]\right)$. The amounts of SS and fluoride removed both increased with the concentration of SDS in every solution and $\varepsilon_{\mathrm{SS}}$ was over $90 \%$ as the concentration of SDS rose to $20 \mathrm{mg} \mathrm{L}^{-1}$ in the solution containing $\mathrm{SO}_{4}^{2-}$ and $\mathrm{HCO}_{3}^{-}$. It is notable that the $\varepsilon_{\mathrm{SS}}$ was not favorable until the concentration of SDS rose to $50 \mathrm{mg} \mathrm{L}^{-1}$ in the solution under the interference of phosphate. This phenomenon should be due to the liberation of $\mathrm{H}^{+}$ions as the $\mathrm{H}_{2} \mathrm{PO}_{4}^{-}$and $\mathrm{F}^{-}$ precipitated with calcium ions to form the insoluble fluorapatite $\left(\mathrm{Ca}_{5}\left(\mathrm{PO}_{4}\right)_{3} \mathrm{~F}_{(\mathrm{s}}\right), \mathrm{Ksp}=10^{-59.5}$ (Morel and Hering, 1993)), as specified in Eq. (10), caused the low pH (5.5).

$$
\begin{array}{r}
3 \mathrm{H}_{2} \mathrm{PO}_{4}^{-}(\mathrm{aq})+\mathrm{F}_{(\mathrm{aq})}^{-}+5 \mathrm{Ca}_{(\mathrm{aq})}^{2+} \\
\quad \rightarrow \mathrm{Ca}_{5}\left(\mathrm{PO}_{4}\right)_{3} \mathrm{~F}_{(\mathrm{s})}+6 \mathrm{H}_{(\mathrm{aq})}^{+} .
\end{array}
$$


Table 3

Effects of the concentration of $\mathrm{SO}_{4}^{2-}, \mathrm{HCO}_{3}^{-}$, and $\mathrm{H}_{2} \mathrm{PO}_{4}^{-}$on the residual SS and fluoride concentration

\begin{tabular}{|c|c|c|c|c|c|c|}
\hline \multirow[t]{2}{*}{ Concentration (M) } & \multicolumn{2}{|l|}{$\mathrm{SO}_{4}^{2-}$} & \multicolumn{2}{|l|}{$\mathrm{HCO}_{3}^{-}$} & \multicolumn{2}{|c|}{$\mathrm{HPO}_{4}^{2-}$} \\
\hline & SS & {$\left[\mathrm{F}^{-}\right]$} & SS & {$\left[\mathrm{F}^{-}\right]$} & SS & {$\left[\mathrm{F}^{-}\right]$} \\
\hline 0 & 4.0 & 10.1 & 4.0 & 10.1 & 4.0 & 10.1 \\
\hline 0.001 & 20.4 & 56 & 104 & 22.6 & 456 & 41.3 \\
\hline 0.01 & 129 & 82 & 484 & 36.4 & 560 & 115 \\
\hline
\end{tabular}

The units of SS and $\left[\mathrm{F}^{-}\right]$are $\mathrm{mg} \mathrm{L}^{-1}$.

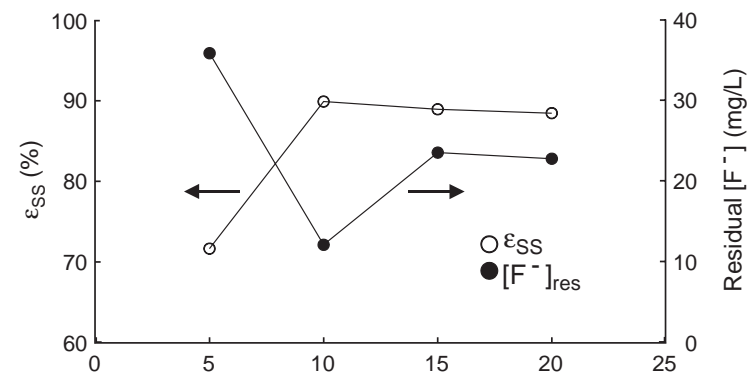

(a)

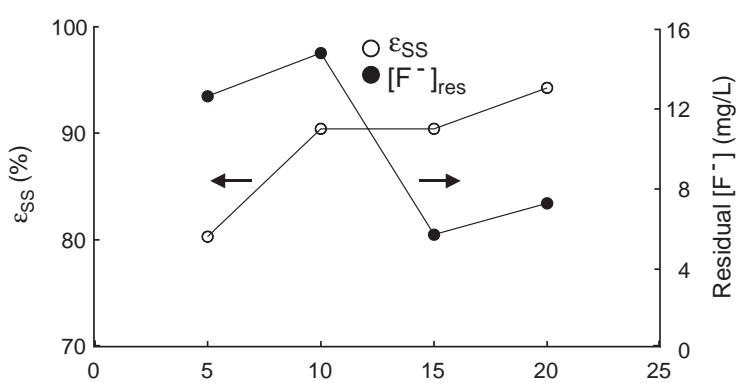

(b)

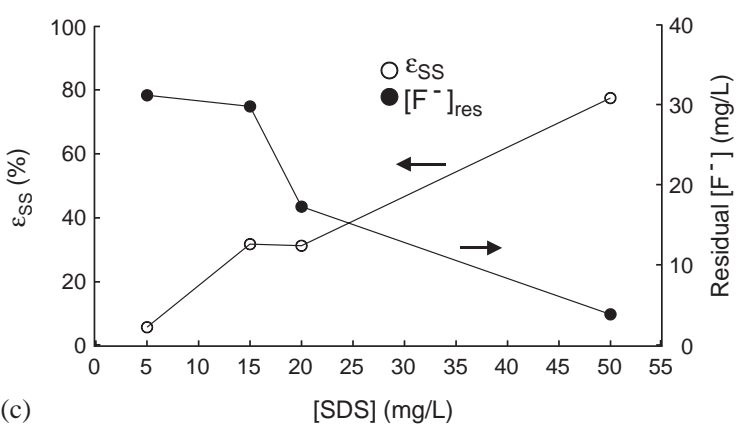

Fig. 5. (a) The variation of the treatment efficiency of SS $\left(\varepsilon_{s s}\right)$ and residual fluoride concentration with the concentration of SDS in the presence of $0.01 \mathrm{M} \mathrm{SO}_{4}^{2-}$ ions $\left(Q_{\mathrm{e}}=864 \mathrm{C} \mathrm{L}^{-1}\right)$. (b) The variation of the treatment efficiency of SS $\left(\varepsilon_{\mathrm{ss}}\right)$ and residual fluoride concentration with the concentration of SDS in the presence of $0.01 \mathrm{M} \mathrm{HCO}_{3}^{-}$ions $\left(Q_{\mathrm{e}}=864 \mathrm{CL}^{-1}\right)$. (c) The variation of the treatment efficiency of SS $\left(\varepsilon_{\mathrm{ss}}\right)$ and residual fluoride concentration with the concentration of SDS in the presence of $0.01 \mathrm{M} \mathrm{H}_{2} \mathrm{PO}_{4}^{-}$ions $\left(Q_{\mathrm{e}}=864 \mathrm{C} \mathrm{L}^{-1}\right)$.
As mentioned above, the decrease of $\mathrm{pH}$ raises the zeta potential of particles and causes low $\varepsilon_{\text {SS }}$. Huang and Liu (1999) reported that the positive zeta potential is reduced by increasing the concentration of SDS. Therefore, raising the concentration of SDS also makes the hydro-fluoro-aluminum particles form stable flocs.

\subsection{Treatment of real semiconductor wastewater}

The wastewater from the etching process is very acidic because a large quantity of hydrofluoric acid (HF) is used to etch wafers and clean quartz. $\mathrm{Ca}(\mathrm{OH})_{2}$ was employed herein to neutralize the solution. The appropriate dosage of lime should be close to half of the concentration of hydrofluoric acid $\left([\mathrm{HF}] \approx 2\left[\mathrm{Ca}(\mathrm{OH})_{2}\right]\right)$, because hydrofluoric acid is the primary source of acidity in the semiconductor wastewater. The appropriate $\left[\mathrm{Ca}(\mathrm{OH})_{2}\right] /\left[\mathrm{Ca}^{2+}\right]_{\mathrm{T}}$ ratio $\left(\gamma_{\text {theo }}\right)$ should be close to the $[\mathrm{HF}] /[\mathrm{F}]_{\mathrm{T}}$ ratio $(\mathrm{Eq} .(11))$, because the total fluoride $\left([\mathrm{F}]_{\mathrm{T}}\right)$ and total calcium $\left(\left[\mathrm{Ca}^{2+}\right]_{\mathrm{T}}\right)$ concentrations added were stoichiometric in this study- $-\left(2\left[\mathrm{Ca}^{2+}\right]_{\mathrm{T}}=[\mathrm{F}]_{\mathrm{T}}\right)$.

$\gamma_{\text {theo }}=\frac{\left[\mathrm{Ca}\left(\mathrm{OH}_{2}\right)\right]_{\text {theo }}}{\left[\mathrm{Ca}^{2+}\right]_{\mathrm{T}}} \approx \frac{[\mathrm{HF}]}{[\mathrm{F}]_{\mathrm{T}}}$.

The dissociation constant of hydrofluoric acid $\left(K_{\mathrm{HF}}\right)$ is $7.2 \times 10^{-4} \mathrm{M}$.

$\mathrm{HF}_{(\mathrm{aq})} \rightarrow \mathrm{H}_{(\mathrm{aq})}^{+}+\mathrm{F}_{(\mathrm{aq})}^{-}, \quad \frac{[\mathrm{H}]\left[\mathrm{F}^{-}\right]}{[\mathrm{HF}]}=K_{\mathrm{HF}}$

The total fluoride concentration $\left([\mathrm{F}]_{\mathrm{T}}\right)$ equals the sum of the concentrations of hydrofluoric acid and fluoride ions

$[\mathrm{F}]_{\mathrm{T}}=[\mathrm{HF}]+\left[\mathrm{F}^{-}\right]$.

Combining Eqs. (12) and (13) yields

$\frac{[\mathrm{HF}]}{[\mathrm{F}]_{\mathrm{T}}}=\frac{\left[\mathrm{H}^{+}\right]}{K_{\mathrm{HF}}+\left[\mathrm{H}^{+}\right]}$.

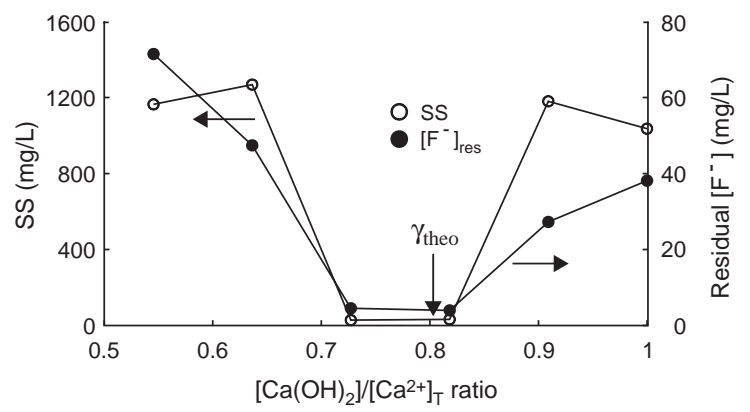

Fig. 6. The variation of the treatment efficiency of SS $\left(\varepsilon_{\mathrm{ss}}\right)$ and residual fluoride concentration with the $\left[\mathrm{Ca}(\mathrm{OH})_{2}\right] /\left[\mathrm{Ca}^{2+}\right]_{\mathrm{T}}$ ratio $\left(Q_{\mathrm{e}}=864 \mathrm{C} \mathrm{L}^{-1},[\mathrm{SDS}]=5 \mathrm{mg} \mathrm{L}^{-1}\right)$. 
Combining Eqs. (11) and (14) gives

$\gamma_{\text {theo }} \approx \frac{\left[\mathrm{H}^{+}\right]}{K_{\mathrm{HF}}+\left[\mathrm{H}^{+}\right]}$.

The $\gamma_{\text {theo }}$ is 0.807 as the initial $\mathrm{pH}$ of the wastewater is 2.52. Fig. 6 presents the variations of the residual $\mathrm{SS}$ and fluoride concentrations with the $\left[\mathrm{Ca}(\mathrm{OH})_{2}\right] /\left[\mathrm{Ca}^{2+}\right]_{\mathrm{T}}$ ratio. The range of suitable $\left[\mathrm{Ca}(\mathrm{OH})_{2}\right] /\left[\mathrm{Ca}^{2+}\right]_{\mathrm{T}}$ ratios was $0.73-0.82$, and the estimated value was in this range. Hence, the amount of lime required to neutralize the wastewater was given by Eq. (15).

The operating current was $0.6 \mathrm{~A}$ and the voltage was $35 \mathrm{~V}$ for the semiconductor wastewater, so the energy consumption was $21 \mathrm{~W} \mathrm{~L}^{-1}$.

\section{Conclusions}

Wastewater from semiconductor manufacturers that contains large amounts of fluoride can be effectively treated by ECF with SDS. SDS can improve the treatment efficiency of the SS. The dosage of SDS in EFC is much lower than that in the DAF or DiAF process, because the $\mathrm{Al}^{3+}$ ions generated from the aluminum electrodes form hydro-fluoro-aluminum flocs in appropriate $\mathrm{pH}$. The flocs were employed as a collector, which can aggregate the $\mathrm{CaF}_{2}$ particles and hydrogen bubbles. The treatment efficiency of SS remains constant while the charge loading exceeds $500 \mathrm{CL}^{-1}$. Interference among co-existing anions - sulfate, carbonate and phosphate - can be mitigated by increasing the dosages of calcium and SDS. The optimal initial acidity is close to that associated with the fluoride concentration following calcium precipitation. The efficiency of the treatment of fluoride and SS falls rapidly when the initial acidity exceeds the optimum value because the hydro-fluoro-aluminum precipitate cannot form stable flocs due to high acidity. The initial acidity of the wastewater can be modified by addition of a suitable amount of $\mathrm{Ca}(\mathrm{OH})_{2}$, which can be estimated from Eq. (15).

\section{Acknowledgements}

The authors would like to thank the National Science Council of the Chinese Taiwan for financially supporting this research under Contract no. NSC 92-2211-E002-028.

\section{Reference}

Brown, W.E., Gregry, J.M., Chow, L.C., 1977. Effects of fluoride on emanal solubility and cariostasis. Caries Res. 11, $118-141$.
Buffle, J., Parthasarathy, N., Haerdi, W., 1985. Importance of speciation methods in analytical control of water treatment processes with application to fluoride removal from wastewater. Water Res. 19, 7-23.

Chuang, T.C., Huang, C.J., Liu, J.C., 2002. Treatment of semiconductor wastewater by dissolved air flotation. J. Environ. Eng. 128, 974-980.

Hao, O.J., Huang, C.P., 1986. Adsorption Characteristics of fluoride onto hydrous alumina. J. Environ. Eng. 112, 1054-1069.

Hu, C.Y., Lo, S.L., Kuan, W.H., 2003. Effects of co-existing anions on fluoride removal in electrocoagulation (EC) process using aluminum electrodes. Water Res. 37, 4513-4523.

Huang, C.J., Liu, J.C., 1999. Precipitation flotation of fluoridecontaining wastewater from semi-conductor manufacture. Water Res. 33, 3403-3412.

Jiang, J.Q., Graham, N., Andre, C., Kelsall, G.H., Brandon, N., 2002. Laboratory study of electro-coagulation-flotation for water treatment. Water Res. 36, 4064-4078.

Lin, M.C., Liu, J.C., 1996. Adsorbing colloid flotation of As(V)-feasibility of utilizing steaming current detector. Sep. Sci. Technol. 31, 1629-1641.

Lui, M., Sun, R.Y., Zhang, J.H., Bina, Y., Wei, L., Lui, P., Keichero, F., 1983. Elimination of excess fluoride in potable water with coarcervation by electrolysis using aluminum anode. Fluoride 20, 54-63.

Lynch, C.F., 1987. Relationship of fluorine in drinking waters to other drinking waters parameters. Arch. Environ. Health $42,5-13$.

Mameri, N., Yeddou, A.R., Lounici, H., Belhocine, D., Grib, H., Bariou, B., 1998. Defluoridation of septentrional Sahara water of North Africa by electro-coagulation process using bipolar aluminium electrode. Water Res. 32, 604-612.

Mansson, A.R., Withford, G.M., 1990. Environmental and physiological factors affecting dental fluorides. J. Dent. Res. 69, 706-713.

Matis, K.A., Mavros, P., 1991. Recovery of metals by ion flotation from dilute aqueous solution. Sep. Purif. Methods 20, 1-48.

Mollah, M.Y.A., Schennach, R., Parga, J.R., Cocke, D.L., 2001. Electro-coagulation (EC) - science and applications. J. Hazard. Mater. B 84, 29-41.

Morel, F.M.M., Hering, J.G., 1993. Principles and Application of Aquatic Chemistry. Wiley, New York, US.

Murugananthan, M., Bhaskar Raju, G., Prabhakar, S., 2004. Separation of pollutants from tannery effluents by electro flotation. Sep. Purif. Technol. 40, 69-75.

Nell, J.A., Livanos, G., 1988. Effects of fluoride concentration in seawater on growth and fluoride accumulation by Sydney rock oyster (Saccostrea commercialis) and flat oyster (Ostrea angasi) spat. Water Res. 22, 749-753.

Parthasarathy, N., Buffle, J., Haerdi, W., 1986. Combined use of calcium salts and polymeric aluminium hydroxide for defluoridation of waste waters. Water Res. 20, 443-448.

Shen, F., Chen, X., Gao, P., Chen, G., 2003. Electrochemical removal of fluoride ions from industrial wastewater. Chem. Eng. Sci. 58, 987-993. 